\title{
An Analysis of Sartre's and Beauvoir's Views on Transcendence: Exploring Intersubjective Relations
}

\author{
Christine Daigle and Christinia Landry
}

This paper will investigate intersubjective relations as conceived by Sartre and Beauvoir. ${ }^{1}$ We will show that there are important weaknesses in Sartre's views and that Beauvoir's divergent understanding of transcendence and embodiment puts her in a better position to articulate a successful existentialist ethics. As we will see, in Being and Nothingness Sartre's notion of transcendence as project, the movement of surpassing facticity, is diametrically opposed to the fleshy immanence of the body. In fact, for Sartre, consciousness as transcendence is constantly trying to outstrip the body. We will show that this struggle between transcendent consciousness and immanent body serves to undermine being-in-the-world and being-with-others (what is, in Sartre's language, only a being-for-others) as a way to enrich the self. With Beauvoir, we will argue that being-with-others must be grounded in an embodied self.

Contra Sartre, Beauvoir formulates transcendence in a way that necessitates bodily immanence. Our examination of Beauvoir's notion of transcendence will reveal that transcendence is not simply a projecting for-itself, which uses the body as an instrument, but rather an upsurge of being which originates in bodily immanence. For Beauvoir, immanence is not the inert passivity of being in-itself, as it appears to be for Sartre. Immanence is the original moment of being (that of joy and delight) which grounds and fashions transcendence. Beauvoir's 
notion of ambiguity shows us that transcendence and immanence are not contradictories. Rather, each necessitates the other.

We take the erotic encounter as the paradigmatic intersubjective relation between two human beings, which allows us to better grasp the possibilities and difficulties in Beauvoir's account of transcendence. For Sartre, the erotic encounter is one wherein a subject makes herself flesh in order to capture and dominate the consciousness of the Other. We reject this as a possible ground for an existentialist ethics. Indeed, a view of intersubjective relations that revolves around domination cannot lead to positive relations, as we will explore below. On the other hand, for Beauvoir fleshy desire is an intermingling of body and consciousness, immanence and transcendence. We disclose ourselves to the Other as flesh in order to experience ourselves as ambiguous, namely, as both a transcendent being of disclosure and an immanent being who is disclosed. Our analysis will show that Beauvoir presents a sophisticated and potentially richer view than Sartre's insofar as immanence is no longer a trap, and transcendence is to be gained only by reveling in immanence. This gesture of putting one's self at risk is the only way to generate an authentic and an ethical encounter with the Other.

The question remains whether Beauvoir can realistically prescribe an existentialist ethics that nullifies the Sartrean problem of embodiment. As we will see, Beauvoir's position is problematic in its own way. However, unpacking both thinkers' notions of transcendence and bringing them into dialogue with one another, we find that locating transcendence in immanence allows for the embodied individual to flourish - even if our ethical relations prove to be a sticky negotiation. $^{2}$ 


\section{Sartre on Transcendence}

Sartre's views on transcendence and immanence evolve dramatically from The Transcendence of the Ego (1936) to Being and Nothingness (1943). Indeed, from an early view whereby transcendence is intertwined with immanence, Sartre moves towards one in which transcendence and immanence are mutually exclusive. It is in The Transcendence of the Ego that we first find a philosophical delineation of transcendence in Sartre's works. Deep into Husserl's phenomenology at the time, Sartre problematizes Husserl's take on the Ego and challenges his notion of the Ego as a mundane object. Wishing to push Husserl beyond his own limits, Sartre proposes to eliminate the duality of the subject/object distinction, and instead offers a consciousness/world totality. Furthermore, Sartre criticizes and rejects Husserl's Ego as useless, harmful, and transcendent: "it cannot be considered to be a structure of transcendental consciousness" (Transcendance de l'Ego 40, our translation). ${ }^{3}$ The Ego is treated by Sartre as an object in the world, although one more intimate than other objects.

Having said only this about Sartre's essay, we already used the concept of transcendence in two different ways that need to be explained. As noted above, Sartre speaks of consciousness as transcendental. Consciousness is defined as conscious of itself, as conscious of a transcendent object. As intentional, consciousness exists only as reaching out of itself, as a movement of projecting itself into the world consciousness is always conscious of. Consciousness is constituted by the objects of which it is conscious. Sartre describes the inner flux of consciousness as immanent. Speaking of how the Ego is constituted, and after having delineated a topology of consciousness according to which there is both a pre-reflective and a reflective consciousness, Sartre explains that there are two types of unity of consciousness: "There exists an immanent unity of these consciousnesses: the flux of consciousness constituting itself as the 
unity of itself. And there exists a transcendent unity: states and actions. The Ego is the unity of states and of actions ..." (Transcendence of the Ego 60-61). Immanence, in Transcendence of the Ego, is the inner unity of itself in consciousness. Something is transcendent if it lies outside of consciousness, and consciousness as a movement is transcendental in that it reaches out to the transcendent; it is constituted by the transcendent object of which it is conscious. Therefore, the immanent unity of consciousness can be said to depend on its movement towards the transcendent. Consciousness as intentionality is transcendence. In itself it is empty and impersonal: "transcendental consciousness is an impersonal spontaneity" (98). Before the transcendent movement nothing exists. The immanent unity is born only after the encounter between transcendental consciousness and the world of objects. The Ego is also born of this encounter:

The World has not created the me; the me has not created the World. These are two objects for absolute, impersonal consciousness, and it is by virtue of this consciousness that they are connected. This absolute consciousness, when it is purified of the $I$, no longer has anything of the subject. It is no longer a collection of representations. It is quite simply a first condition and an absolute source of existence. $(105-106)^{4}$

In The Transcendence of the Ego we see that "immanence" and "transcendence" are used in a special way. Immanence is used to refer to the inner unity of consciousness - the inner consolidation of whatever is gathered by consciousness' transcendental movement out of itself. Transcendence is that which lies "outside" of consciousness, namely as being coextensive to consciousness, yet being founded outside of consciousness. Is this immanence not "transcendental" by nature? Insofar as it is constituted by intentional consciousness, it would have to be such. In The Transcendence of the Ego, then, Sartre presents immanence and transcendence as intertwined and not in opposition. ${ }^{5}$ There is, however, a shift in how he approaches this in Being and Nothingness. This shift allows him to state, in "Conscience de soi et 
connaissance de soi" (1947), ${ }^{6}$ well after the publication of his magnum opus (from which this statement is taken originally), that "If consciousness is transcendent, this means that it is born as carried by a being that is not it ... [A] non-conscious and transphenomenal being of which it is conscious is implied in its being" (Sartre, "Conscience" 137, our translation). ${ }^{7}$ On the surface, things have not changed much since The Transcendence of the Ego. Consciousness is still intentional, and as such depends on transphenomenal being to constitute itself. But consciousness is now described as "transcendent" rather than "transcendental," as an intentional movement towards the transcendent. What happened?

In Being and Nothingness, Sartre revisits and refines his views on consciousness. As intentional, consciousness projects itself out of itself and thus constitutes itself. As such, consciousness is transcendent. It is freedom - an "arrachement à soi" (a tearing away from oneself). Consciousness can transcend towards transphenomenal being because it is not being, it is nothingness; it is "a nihilation which is exercized in the very heart of immanence" (Being and Nothingness 84$).{ }^{8}$ In this context, Sartre defines immanence as the pure subjectivity of the cogito. But this pure subjectivity is precisely nothing. It is a nothing that constitutes the pure possibility of my transcending. It is also what allows consciousness to be present to itself. Consciousness exists at a distance from itself as present to itself. The distance is nothing yet it allows for consciousness to be conscious of itself as present to itself. In the chapter titled "Transcendence," Sartre continues and explains that the relation between the for-itself, conscious being, and the in-itself, non-conscious being, is constitutive of the for-itself. This relation is the encounter between consciousness and transphenomenal being. Transcendence is "that inner and realizing negation which reveals the in-itself while determining the being of the for-itself" (249). Negation is a fundamental transcendence, one that makes "thises" (that is, the things or objects 
encountered by consciousness) ${ }^{9}$ exist. While present to the in-itself, consciousness discriminates between thises, as well as discriminates between itself and that which it is not. It can differentiate as negation, as transcendence.

Fundamental negation thus constitutes a necessary position from which consciousness emerges as transcending. This nothing, this immanence, allows for intentional consciousness to unfold as transcendence. Likewise, the body constitutes itself as the factical anchorage for transcendent consciousness. Sartre explains that my body is "as the surpassed; it exists only in so far as I escape it by nihilating myself. The body is what I nihilate" (409). The body, like the present, like the nothingness of consciousness, is the vantage point and origin for the movement of my transcendence. It is the condition of my action, of my meeting the in-itself. It is the contingent condition of my intentional consciousness (conscious of) and thus of my transcending project towards the future. It serves as a hinge, much like the present that articulates the past and the future for consciousness (430-432). Yet the hinge is empty. ${ }^{10}$

Speaking of the body, Sartre says that consciousness of the body is an original affectivity that equals a consciousness of the world — an immanence. The body and the world constitute the background of consciousness. ${ }^{11}$ The body, like the world, is present as a totality at every moment, in every action, in all transcending. But unlike the world, it is present as that which allows the transcending movement of my consciousness, a movement towards the world. The facticity of my body is that which my consciousness transcends at every moment and it is the necessary condition of the transcending. The body is pure contingency of presence (Being and Nothingness 506) and desire, intimately tied to desire for flesh, namely a means for consciousness to be glued in/to the world. The body is equated with immanence, perpetually transcended by consciousness. It is that which the free project nihilates and flees. ${ }^{12}$ 
Sartre's reading of the body problematizes his notion of sexuality. ${ }^{13}$ At the same time that he wants to explain how, in sexual desire, transcendence longs for the immanent, he paradoxically insists on the negative and threatening aspects of this desire. It seems as if Sartre wants it both ways: an embodied consciousness that entails an intermingling of immanence and transcendence and a consciousness that seeks to evade its fleshy being, that is, a transcendence radically separated from immanence. In Being and Nothingness, Sartre discusses how the body is a fleshy thing that consciousness may use in an instrumental way. ${ }^{14}$ Furthermore, he explains that one may even disregard one's embodied being. Thus the woman at the romantic rendez-vous successfully dissociates herself from her body. The man she is out with takes her hand and she does not notice that she is letting him do this "because it happens by chance that she is at this moment all intellect ... And during this time the divorce of the body from the soul is accomplished; the hand rests inert between the warm hands of her companion-neither consenting nor resisting — a thing" (97). This example arises in the context of the analysis of bad faith. However, what is interesting here is the fact that the split between transcendent consciousness and the immanent body is declared to be possible: the woman's hand, that bodily part that she lets the man grab, is "a thing." Moreover, this divorce is triggered by desire, but in an almost contrary sense, as the woman does not want to be entangled in ambiguous fleshy desire. Her consciousness does not want to be drawn into the immanence of her body and seeks to evade it. Thus, she makes of her own hand a thing, she negates it and transcends it.

Sartre's discussion of sexual relations confirms the possibility of this split between the body and consciousness - the evasion of transcendence from immanence. In sexual relations, the for-itself uses its body as an instrument. Wanting to seduce and fascinate the Other, it makes itself into an object in the attempt to capture the Other's subjectivity. What consciousness 
desires, ultimately, is not the body of the Other, rather it is the consciousness of the Other, namely, the body as a means to reach consciousness. The body is merely a bridge and the desiring consciousness is not desiring to transcend itself in immanence. In sexual relations, the encounter of fleshy bodies is one in which consciousness seeks to "touch" the Other's consciousness: transcendence aims at transcendence. Its path to the Other's transcendence is through the sexual desire felt in its own body for the immanent body of the Other. Consciousness as transcendent dreads its being swallowed by the immanent fleshy body, whether it is its own body or that of the Other. This dread becomes clear in Sartre's analysis of slime and holes.

The slimy is both appealing and disgusting to the for-itself. For Sartre, slime is the "revenge of the In-itself" as the for-itself who dares touch it "risk[s] being dissolved in sliminess" (Being and Nothingness 777). The risk is for consciousness to be ensnared in the slimy, in stagnation, in the immanent. The slimy horrifies the transcending for-itself because it represents the impossibility of transcending oneself. On the other hand, holes are fascinating for consciousness. Children, in particular, are attracted by them: "the hole is originally presented as a nothingness 'to be filled' with my own flesh; the child can not restrain himself from putting his finger or his whole arm into the hole. It presents itself to me as the empty image of myself" (781). Holes are appeals to the for-itself: the hole, which is nothing more than emptiness, wants to be filled. Sartre proceeds to explain that the for-itself, the only being for whom there can be holes, sacrifices his body to make the plenitude of being exist. The for-itself sacrifices itself so as to preserve the totality of the in-itself. In the process, what is being sacrificed is the body of the for-itself, its immanent, factical, non-transcending being.

Sartre's next step brings him to a discussion of the female genitalia. ${ }^{15}$ The analysis of slime and holes thus takes him back to the sexual fleshy encounter of transcending 
consciousnesses. The following passage is crucial in understanding Sartre's position and how it is problematic:

The obscenity of the feminine sex is that of everything which "gapes open." It is an appeal to being as all holes are. In herself, woman appeals to a strange flesh which is to transform her into a fullness of being by penetration and dissolution. Conversely woman senses her condition as an appeal precisely because she is "in the form of a hole" ... Beyond any doubt her sex is a mouth and a voracious mouth which devours the penis - a fact which can easily lead to the idea of castration. The amorous act is the castration of the man; but this is above all because sex is a hole ... Nevertheless the experience with the hole, when the infant sees the reality, includes the ontological presentiment of sexual experience in general; it is with his flesh that the child stops up the hole and the hole, before all sexual specification, is an obscene expectation, an appeal to the flesh. (Being and Nothingness 782)

Because it lacks the self-completeness of being and wants to be in-itself, consciousness attempts, by making use of its body as instrument, to fill being, thus to merge itself in a fullness of being. However, a consciousness that would become in-itself would no longer be consciousness. As transcendence, consciousness requires that it does not equate itself, that it be not in-itself. If it was successful in merging with the fullness of being, in being in-itself, it would no longer be a movement of transcendence, it would simply be. Therefore, when transcendence turns towards immanence in an attempt to fill being, using its immanent being as flesh to fill holes, transcendence is aiming at its own annihilation qua transcending consciousness. The reveling in immanence entails an entanglement in immanence that is threatening for transcendence as it can lead to its annihilation. In the above description, the male for-itself, embodying transcending consciousness, encounters the gaping feminine immanent hole that secretes slimy mucus and is put at risk of losing himself in the encounter, of being devoured by the immanent. This is the fear of being lost in immanence. ${ }^{16}$

Because even the closest encounters between human individuals are tainted by this dread of being absorbed into the immanent, relationships are inherently conflictual. The encounter is 
always risky and transcendent consciousness seeks to flee its immanence, or that of the Other, for fear of seeing its own end. This kind of view is very unlikely to yield a positive ethical theory, and in fact, it does not. ${ }^{17}$ Recall that since we are embodied beings and since our consciousness as transcendence finds its anchoring point in our fleshy beings, Sartre's attitude towards the body as a mere immanent tool sets up interpersonal relations to fail. The consciousness that considers its own body as a tool is not authentic about its own self. Further, considering the Other's body as an instrument is problematic in two ways: 1) it entails a failure to recognize the Other as a free consciousness, as one's peer, and 2) this misrecognition opens the door to oppressive relations. It is interesting that Sartre himself had a sense of this when he analyzed various relations with others. All such relations end in conflict and violence, leading Sartre to his damning statement: "The essence of the relations between consciousnesses is not the Mitsein; it is conflict" (555). Thus, in Being and Nothingness, Sartre fails to find a way by which for-itselves can, as ambiguous beings - that is, as beings that are both immanent and transcendent-positively relate to one another, even in what seems to be the least risky relationships: love and intimate sexual relations. ${ }^{18}$ On the contrary, Sartre's analysis of these relations demonstrates that reveling in immanence is dangerous for transcendence and this is why transcendent consciousness seeks to conquer and dominate the Other's fleshy/immanent appeal to oneself.

\section{Beauvoir on Transcendence}

Although the ground for Sartre's existentialist ethics is at best shaky, we argue that it is Beauvoir's attention to the first intentional moment (disclosure) and not the second intentional moment (transcendence) that allows for her ethics to stand on firmer ground. The first intentional 
moment is described by Beauvoir to be a moment of joy that opens the self to the Other and stands in an ambiguous relationship to the second intentional moment. The second intentional moment is marked by the identification of the "I" of consciousness with the being it discloses; as we discovered above it is this moment that Sartre privileges. Although we can find hints of Sartre's thinking in Beauvoir's work, ${ }^{19}$ her philosophical originality, her rethinking of intentionality as being at the same time disclosure and transcendence, can be read as early as "Pyrrhus and Cinéas."

In "Pyrrhus and Cinéas," Beauvoir's work differentiates itself from Sartre's later ontologico-phenomenological notion of consciousness as transcendence. Instead, Beauvoir describes a more nuanced notion of embodied transcendence, one which is marked by an individual's activity in the world and her relation to the Other; she is more than simply an intentional being. She characterizes transcendence as activity that finds its opposite in passivity. Human beings are deemed transcendent insofar as they are involved in projecting themselves beyond their passive facticity and towards a future as beings for themselves ("Pyrrhus" 121). Beauvoir explains, "We are free to transcend all transcendence. We can always escape toward an 'elsewhere,' but this elsewhere is still somewhere, in the heart of our human condition" (141). Here, transcendence, as moving beyond the mere being in-itself, and arguably the being foritself, is similar to the Sartrean ontological framework as that which surpasses even itself. However, Beauvoir is careful to acknowledge the worldly component, namely the humanness, of our surpassings. It is one's facticity that anchors the human being in the world, colouring the possibilities of the striving for-itself. Beauvoir's transcendence finds itself rooted in a social and material world that can be eclipsed, but never outstripped. 
In "Pyrrhus and Cinéas," Beauvoir differentiates between two types of transcendence: transcendence as generosity and transcendence as project. ${ }^{20}$ She thereby begins taking her distance from Sartre's views on transcendence. In Beauvoir's early work generosity is described as a type of transcendence that is arguably crucial to the sort of intersubjectivity she has in mind throughout her ethical works - an intersubjectivity founded on mutual freedom. However, at this early stage Beauvoir is preoccupied with the existential flavour of generosity and not the phenomenological reading that will enrich her later texts. Generosity is described in "Pyrrhus and Cinéas" as an act of finitude. It is an act that is an end in itself. Thus, it is easily confused with transcendence as project, which is described to be an act of universality—an affirmation of values that relates the subject to others. In this second reading, Beauvoir is in agreement with Sartre's notion of transcendence.

Generosity is a bit different. According to Beauvoir, generosity wants only to be received as a free act. Beauvoir explains, "Generosity wants and knows itself to be free and asks for nothing but to be recognized as such" ("Pyrrhus" 124). Unfortunately, generosity can be mistaken as purely factical action or a self-interested action. ${ }^{21}$ What is particularly important to note about generosity in both cases of mistaken identity, is that it cannot be for the Other given that in "Pyrrhus and Cinéas" we cannot do anything for the Other. This does not mean that it is for the self rather in a way it is for all of humanity. Lucid generosity reveals that one cannot do anything for others ("Pyrrhus" 124). This means that in acting generously (and arguably acting in any fashion towards the Other) we can only reach the exterior of the Other since we can never reach the interiority of another being. ${ }^{22}$ Therefore, generosity is truly only for its own end. Similarly to generosity, violence also only reaches the exterior of the Other. Beauvoir argues, "Violence can act only upon the facticity of man, upon his exterior. Even when it stops him in 
his élan toward his goal, violence does not reach him in his heart because he was still free in the face of the goal that he proposed to himself" (124). At this point, Beauvoir has yet to fully distinguish her notion of transcendence from Sartre's notion insofar as transcendence remains intimately intertwined with the upsurge of intentionality. As we can see in this quote, Beauvoir, like Sartre, does not at this point acknowledge the possibility of oppression. Consciousness seems to be out of reach within the body. This separation haunts the ground of Sartre's ethics and gestures towards the impossibility of an existentialist ethics.

Generosity hints at the possibility that there can be an exchange between two that is neither merely for the self nor merely for the Other. As Beauvoir will later explain, "generosity seems to us to be better grounded and therefore more valid the less distinction there is between the other and ourself and the more we fulfill ourself in taking the other as an end" (Ethics of Ambiguity 144). As we will explore below, Beauvoir is suggesting that it is through generosity that we are able to not only nurture the freedom of the Other, but also to bestow value in the freedom for all by taking the Other as an end in herself, which necessarily includes taking our own freedom seriously. The caveat is that generosity must find its grounding in something. Although Beauvoir does not flesh out her notion of transcendence as generosity beyond "Pyrrhus and Cinéas," it preoccupies her for much of The Second Sex, especially given her attention to embodiment as the potential grounding for what we understand to be relationships of generosity. ${ }^{23}$

In The Ethics of Ambiguity, Beauvoir stays true to the Sartrean distinction between being and existence as it is used in Being and Nothingness. Being is the in-itself. Existence is the foritself; it is the lack of being. Consciousness discloses being to existence and weds the two. Consciousness desires to be that which it discloses. This, of course, is impossible. Human 
transcendence never fulfills itself as project for it opens itself indefinitely to the future (Ethics of Ambiguity 130). By way of this upsurge, the subject makes herself a myriad of aspects of being (40). By projecting herself in the world she creates possibilities (points of departure) for other transcendences. Through transcendence, as a free action, the subject discloses meaningful projects in the world.

For Beauvoir, freedom is the source of all values and provides us with the basis for moral justification. Original freedom (lived freedom which is uncoerced) discloses values that can be justified through reflective consciousness. It is this move from original freedom to moral freedom at the hands of reflective affirmation that uncovers the space for moral justification. Since lived freedom is uncoerced, it tacitly asserts itself as valuable. The fact that an action is taken freely carries with it not only the value of that action, but that which permits the creation of that value, namely, the original freedom involved. In Beauvoir's ethical thinking, freedom takes its place as that which supports all value-making. Therefore, it is not enough to act freely: we must desire freedom above all else. We must actively will not only our own freedom, but also the freedom of all others, because our freedom depends on that of others. Beauvoir argues by analogy, "In order to be recognized by them, I must first recognize them. Our freedoms support each other like the stones in an arch, but in an arch that no pillars support" ("Pyrrhus" 140). The reflective process unveils this bond between agents and endows our free actions with an implicit moral component - the willing of freedom for ourselves and for others, or a space for objective justification. $^{24}$

Unlike the freedom proposed by Sartre, Beauvoir's notion of freedom depends on our relations with others. We are not absolutely free because we are always entrenched in our relations with the world and with other free agents. ${ }^{25}$ This intersubjective reality colours our 
original freedom and the possibilities for willing the freedom of others. Beauvoir's view rightly calls attention to our situatedness in an intersubjective world, whereby we are born into a certain culture, religion, ethnicity, race, gender, sexuality, class, and so forth. This means that our ability to act freely and reflect on those actions is tacitly bound by our situation. Consequently, that which we hold to be valuable is not fully born out of original freedom, but it is born from the freedom that our situation permits. For as we can all attest, our situation rarely allows for radically free action given the complex ways in which we are situated with respect to other freedoms. We are always firmly rooted in our facticity. This undoubtedly shapes our avenues for appealing to others. For example, as we have explained with Sartre, when a woman's body is characterized as constituted by a lack of being it is evident that the ways in which she can appeal to an other are circumscribed by this visible lack. ${ }^{26}$ One thing that is certain is that whatever else people might want in affirming their existence they will also want freedom. For we not only have goals, but we also have the desire to pursue those goals. Regardless, we want to be selfdetermining. However, this is only possible if we possess the freedom to pursue our life for ourselves. This freedom depends on the generosity of the Other. While Beauvoir acknowledges this, Sartre misses this key relationship that must hold for an existentialist ethics to be possible.

In a space where each agent only has as much freedom to transcend as her situation allows, she is constantly faced with competing transcendences. Furthermore, given our grave discrepancies in relations of power, our intersubjective reality limits our freedom and our reflective capabilities (contra Sartre). It does not seem fair that only those of us privileged enough to critique our actions can posit or withhold moral freedom. Beauvoir writes, "every man needs the freedom of other men, in a sense, always wants it, even though he may be a tyrant; the only thing he fails to do is to assume honestly the consequences of such a wish. Only the 
freedom of others keeps each one of us from hardening in the absurdity of facticity" (Ethics of Ambiguity 71). We always desire the freedom of others to recognize the meanings that we create, whether they are generous or constructive qua project. However, the degree to which we are recognized will always vary and recognition from some will be more valuable to us than that from others. There is no law of exchange in interpersonal relations by which to gauge reciprocity. Much of what is exchanged is done so unknowingly_-generously ${ }^{27}$ —and, therefore, falls outside of a quantifiable realm of currency. It is an end in itself and thus, it does not confirm any values over and above generosity. Even if we are transcendent beings, we cannot always liberate ourselves from our current reflective situation, nor is it desirable that we do so. We can will the freedom of others by opening the space of possibilities for other subjects. This is achieved by becoming vulnerable for the Other through generosity. However, transcendence as generosity is precarious.

Generosity in practice is shot through with a very selective forgetting. Rosalyn Diprose explains, "It is in the systematic, asymmetrical forgetting of the gift, where only the generosity of the privileged is memorialized, that social inequalities and injustice is based" (Diprose 8). We can open a space of possibilities for others through our generous acts, as Beauvoir suggests, but this space is risky. Social privilege, a factor to which Beauvoir is keenly attuned in The Second Sex, determines (and is determined by) the extent to which the space opened through generosity is used to ground one's projects, but is forgotten as integral to those projects and the values that they affirm. For instance, the generosity of woman as children's primary caregiver is historically negated by the economic generosity of man. Her gifts are forgotten or mistaken as factical or egoistical (they are not freely given) and his are memorialized. By watching the children she makes it possible for him to earn money. Consequently, generosity in practice faces the task of 
overcoming this critique of misrecognition or perpetuating the status quo if it is to stand as an ethical possibility that nurtures our relations with others. Beauvoir locates the key to generosity in the joy of giving.

There is delight to be had in generosity. Generosity is not just the proverbial doormat of transcendence as project. It is through generosity that we are able to nurture the freedom of the Other and to bestow value in the freedom for all. We are able to disclose ourselves as the creators of meaning through generosity. This means that we can tend to the élan of being as transcendence and also foster an intersubjective realm marked by reciprocity. According to Beauvoir, becoming a for-itself-in-itself is not the central concern of our being. Disclosure of the in-itself by the for-itself can be better satisfied through generosity. Existence, as such, is its own end. In fact, dwelling freely in one's body amongst other free beings is, for Beauvoir, the original type of being as existing. ${ }^{28}$ This type of being is marked by joy, but notice that joy with others requires the liberty of others as well.

Beauvoir's break with Sartre is still not complete in The Second Sex. In it, transcendence retains the flavour of temporality, action, and freedom, and so Beauvoir remains categorically loyal to Sartre's three ek-stases of the for-itself as described in Being and Nothingness. ${ }^{29}$ However, she uses these meanings of transcendence with a different aim, namely, promoting reciprocity between competing transcendences instead of using them to delineate an ontology. Contra Sartre, transcendence is very much a lived concept for Beauvoir. She begins her magnum opus by explaining,

All subjects are given concretely and through their projects they have achieved freedom only in their perpetual going beyond towards other freedoms. There is then another justification of existence, namely, the expansion towards an indefinitely open future. Each time a transcendence falls back into immanence there is a degradation to the "in-itself;" 
freedom into facticity. This fall is a moral fault if the subject authorizes it; it takes the figure of frustration and oppression. It is in both cases an absolute evil. (Second Sex xxxivv)

In The Second Sex, we are introduced to the Beauvoirian notion of immanence. She contrasts immanence with transcendence throughout The Second Sex by describing transcendence as constructive activity, progression, and freedom from facticity. Conversely she describes immanence as life-sustaining activity, passivity, and submission to facticity. Transcendence and immanence are therefore not to be thought of as metaphysical concepts, but rather as modes of existence. Furthermore, unlike Sartre in Being and Nothingness, both immanence and transcendence remain within the realm of consciousness.

In The Second Sex the notion of transcendence is at odds with that of Sartre, even in those passages where Sartre is present. Though transcendence is a surpassing of immanence, it is founded upon immanence, namely our being in the world as factical beings. According to Beauvoir in the "Introduction," we can choose to expand towards an indefinite future or we can fall back into facticity. In contradistinction to Sartre, both transcendence and immanence are consciously elected. Consciousness then presides over the upsurge of transcendence and the passivity of immanence. Ultimately, the subject is free to transcend only insofar as she is situated. Our situation is the basis for transcendence, that which must be extended beyond our immanence save a moral fault. Beauvoir writes, "We can never separate the immanent and the transcendent aspects of living experience: what I fear or desire is always an embodiment of my own existence" (Second Sex 161). In order to project oneself in the world, we must have a position in the world from which to act. Although our situatedness provides the grounds for transcendence, it does not necessitate transcendence. In fact, one's situation often closes off the possibilities for transcendence unbeknownst to the individual wherein there is no moral fault. 
Our situation bears its own burden. Beauvoir seems to underestimate the weight of situation in The Ethics of Ambiguity as she asserts an original freedom for all. However, she finds herself reeling under the weight of women's situation in The Second Sex. Transcendence and immanence as two modes of existing are typified in Western society's gender roles. Men are transcendent subjects through the creative, productive activities in which they typically engage, and women are immanent Others through the life-affirming reproductive activities in which they typically participate. ${ }^{30}$ Beauvoir's investigation shows that neither men nor women are naturally more immanent or naturally more transcendent than the other sex. Consciousness can swing either way; however, socio-biological constructions of embodiment aid in determining whether we dwell in immanence or expand through transcendence. Beauvoir explains,

man, like woman, is flesh, therefore passive, the plaything of his hormones and of the species, the restless prey of his desires. And she, like him, in the midst of the carnal fever, is a consenting, a voluntary gift, an activity; they live out in their several fashions the strange ambiguity of existence made body. (Second Sex 728)

Beauvoir believes the human being to be both immanent and transcendent, ambiguous in nature, and, therefore, living out one's situation as primarily immanent or as primarily transcendent is inauthentic. It is because Beauvoir holds the individual to be fundamentally ambiguous that she, unlike Sartre, is able to conceive of reciprocal relations between subjects.

Beauvoir advocates ambiguity — a passageway between immanence and transcendence wherein one aspect of being never completely eclipses the other. Human beings are fundamentally ambiguous with respect to time, others, and intra-subjective being. Beauvoir writes, "The fact is that every human existence involves transcendence and immanence at the same time; to go forward, each existence must be maintained, for it to expand toward the future it must integrate the past, and while intercommunicating with others it should find self- 
confirmation" (Second Sex 430). We cannot separate the immanent from the transcendent, as Sartre attempted. We cannot move completely beyond our facticity. However, this is not necessarily a dynamical relation. An individual can exist in her immanence without the possibilities for transcendence. Oppression can relegate an individual to immanence. Beauvoir shows us that, as human beings, we are necessarily embodied. This aspect of our being has ontological priority over transcendence. The conditions under which we are as beings inform our possibilities for existence. For Beauvoir, transcendence is transcendence in immanence and not transcendence as a fleeing from immanence, as Sartre would have it. Therefore, the élan of being is possible only insofar as we are situated embodiments in the world who actively will a space which will allow for our own freedom and the freedom of our peers to transcend in immanence. This dynamic makes it necessary to affirm transcendence as generosity given that generosity provides the grounds for freedom to flourish. A space of possibilities wherein one can peruse her projects is opened up.

First, in order to affirm transcendence as generosity, generosity needs to be separated from mere facticity. Willing the freedom of the Other through benevolence is more than simply a factical character trait. Second, generosity needs to be understood as a way by which not only to affirm the importance of the Other, but to also affirm the importance of the self. In assuring the freedom of the Other, an individual is upholding freedom as valuable for all, both the individual and the Other. Transcendence as project cannot hope to establish an ethical way of being merely through the affirmation of the self. This is particularly problematic for Sartre's ethics both in his later separation of immanence from transcendence (there is no genuine situatedness of the transcending subject) and in his affirmation of transcendence as project (there is no concern for 
others because the transcending subject does not bear the weight of her situation as being fundamentally with other freedoms).

For Beauvoir, generosity takes on a new life in her notion of lived ambiguity. Ambiguity, as an avowal of embodied consciousness, affirms one's situatedness among others and one's ability to transcend. Ambiguity is overtly typified for Beauvoir in the intermingling of body and consciousness in the consensual erotic encounter. Recall that although consciousness is embodied, it can obscure its own bodily being. However, the erotic encounter makes evident our being as fleshy desire that is both immanent and transcendent. In this space, ambiguity affirms the importance of self and Other. The erotic encounter as described by Beauvoir in The Second Sex simultaneously highlights the importance of both immanence and transcendence in our being-with-others. Beauvoir explains, "the delight the lovers give and take in mutual recognition of their freedom is what lends strength and dignity to physical passion; under these circumstances nothing they do is degrading, since nothing is a matter of submission, everything a matter of willing generosity" (444). It is through ambiguously being with an Other that we can be more than for-ourselves as transcendent project or for-others as immanent body. This space is not to be conflated with the Sartrean for-itself-in-itself; ${ }^{31}$ rather it is characterized by ambiguity: a mutual free exchange of generosities. Transcendence as generosity is an acknowledgement of our peers as embodied freedoms. However, we would be amiss if we did not detect a problem in Beauvoir's notion of generosity.

\section{Beauvoir Transcending Sartre: On the Way to an Existentialist Ethics}

We have seen the apparent success of Beauvoir, vis-à-vis Sartre, let us now turn to examine whether or not Beauvoir has a firmer foothold on developing an existentialist ethics 
than does Sartre. In "Must We Burn Sade?" Beauvoir writes, “The state of emotional intoxication allows one to grasp existence in one's self and in the other, as both subjectivity and passivity. The two partners merge in this ambiguous unity; each one is freed of his own presence and achieves immediate communication with the other" (32-33). ${ }^{32}$ This relationship sounds idyllic in the face of Beauvoir's shifted concern in her later writings. It is as if she has forgotten the weight of situation so aptly described in The Second Sex. We must ask: is it truly possible (given the weight of situation) to merge in an ambiguous unity with an other, or rather, the more interesting question given the tenor of this article is: can we live our bodies ambiguously (somewhere between immanence and transcendence), and if so, is this truly a more authentic way to live than in a Sartrean state of transcendence that seeks to escape its immanence?

Let us return to woman's situation for a moment. In The Second Sex, Beauvoir argues that due to the socio-historical situation of woman, acts of generosity are perceived to be merely immanent. Woman's generosity is subsumed under her socio-historical situation as immanent whereby cooking dinner and raising children are no more than necessary daily tasks to which woman is relegated. She is the inessential Other. Perhaps it is even the case that her sociohistorical situation is grounded in the exploitation of her generosity. In Beauvoir's account, when woman does transcend she does so more through generosity (a reaching out towards the Other) than through the project. Therefore, either woman is confined to immanence (denied the liberty to choose her life) or transcend through generosity - a sort of perverted ambiguity wherein she is trapped between her own being-for-others and being-for-herself through acts of generosity. Now only if we conceive of ambiguity in the romanticized view of generosity, as mutually reciprocated in fleshy desire, could ambiguity be possibly conceived of as authentic existence. Otherwise, ambiguity is no more than a catch-22 within which woman is ontologically located 
for it is only in the rare cases of mutually reciprocated generosity wherein ambiguity is a desirable way to live.

One can live ambiguously indeed as the oblivious housewife overtly demonstrates, but what good is ambiguity if it merely ensnares us between being for ourselves and being for an other. It is difficult to strike a balance between being for the Other and being for the self in ways that both nurture one's own projects and the projects of the Other. Only in the rare cases of mutually reciprocated generosity is ambiguity a desirable way to live. Whether it is in fact sustainable is also a point of contention. Even though Beauvoir conceives of the problem of intersubjectivity differently than Sartre and gives a more nuanced account of our relations with others, she nonetheless returns to the Sartrean dilemma. How can we live authentically with others? We should not forget, however, that for Beauvoir ambiguity reaches beyond our relations with others. Indeed, living ambiguously with others is merely a part of a bigger picture. One must, as an individual, pursue one's own projects and remain open to the world and to others. This means that the individual's life as project is both unstable and ongoing. The ambiguity of our relations with others further complicates the fundamental ambiguity of our being which we must maintain and experience as ambiguous.

The solution Beauvoir proposes is attractive. However, a careful examination shows that ambiguity also has its own set of problems. Her thinking about the movement between immanence and transcendence as ambiguous living outstrips its possibilities. Namely, Beauvoir romanticizes this passageway between immanence and transcendence by demarcating it as a space of generosity wherein each individual can live ambiguously. However, the only way generosity can flourish is if it is accepted as a truly free act. This is highly suspect given Beauvoir's attention to situation and the way in which we conceive of the projects of others as 
rooted in facticity or merely egotistical. We can see that the situation of woman as sociohistorically situated as ambiguous does not bring us any closer to what it means to live authentically. Perhaps Beauvoir falls prey to the same difficulties as Sartre after all. Whether she in fact does fall prey remains to be seen: this question ought to be the object of a separate inquiry into how each thinker elaborates ethical proposals on the basis of their understanding of intersubjective relations.

\section{$* * *$}

The notion of transcendence proves to be problematic in formulating an existentialist ethics in both the works of Sartre and Beauvoir. Sartre's divorcing of the transcendent for-itself from the immanent body runs into difficulties when trying to account for psychological and physical oppression. Transcendence, for Sartre, is the recipe for dominance. However, his notion of unfettered freedom does not take seriously enough the severity of oppression because it fails to account for our bodily situation, relegating it to the realm of immanence from which consciousness, as transcendent, must and does flee. Beauvoir runs into a different but equally challenging problem. Locating transcendence in immanence serves her well in accounting for the body in situation, unlike Sartre. However, it is the notion of body in situation that demonstrates the tricky nature of her hopes for ambiguous living. Perhaps it is not just the ontological difficulties in the thinking of Sartre and Beauvoir which prove challenging in establishing an existentialist ethics. Indeed, it may just be existentialist ethics' failure or unwillingness to substantiate a transcendent (metaphysical) grounding which is the real hurdle. That, however, would entail that all ethics is necessarily metaphysical, something which would be unacceptable 
to both Sartre and Beauvoir. They would much rather deal with an ethics that is nonmetaphysical despite all its difficulties. If they are right, then maybe we ought to conclude that ethics is a messy business after all.

\section{Notes}

${ }^{1}$ We wish to thank the reviewers of our paper for their helpful suggestions and criticisms, which have helped improve this paper.

${ }^{2}$ In "The Concept of Transcendence in Beauvoir and Sartre," Andrea Veltman has also inquired into the notion of transcendence in Beauvoir and Sartre. Her approach, however, is different than ours since we focus on the ethical implications of their diverging views on transcendence. While our article investigates one aspect of the Sartre-Beauvoir intellectual relationship by comparing their understanding of the concepts of immanence and transcendence, it is not an essay on the question of influence. Many scholars have tackled this thorny issue, mostly with an aim to establish Beauvoir as a philosopher and to pull her out from under Sartre's crushing shadow. Seminal work by Margaret A. Simons and Sonia Kruks has launched a series of inquiries on the question of influence. For more, see Daigle and Golomb, Beauvoir and Sartre.

${ }^{3}$ De Coorebyter's original reads: "il ne peut en aucune façon être tenu pour une structure de la conscience transcendantale" (40).

${ }^{4}$ For key analyses of Sartre's concept of transcendence as it pertains to the ego and his critique of Husserl, see Phyllis Sutton Morris and Stephen Priest.

${ }^{5}$ This would hold true even if we used more traditional ways of defining transcendence and immanence. If immanence refers to the world and if transcendence refers to how one may surpass oneself, keeping in mind that Sartre denies the existence of an afterworld or otherworldly, then transcendence is still to be achieved immanently. One will transcend oneself in this immanent world. Transcendental consciousness builds its ego and other objects in an immanent way.

${ }^{6}$ Sartre delivered the talk "Conscience de soi et connaissance de soi" in 1947. As far as we are aware, this essay has not been translated.

${ }^{7}$ Sartre's original reads: "Si la conscience est transcendante, cela signifie qu'elle naît portée sur un être qui n'est pas elle ... implique dans son être un être non-conscient et transphénoménal, dont elle est conscience” (“Conscience” 137) 
${ }^{8}$ Interestingly, this sounds similar to an argument that Beauvoir makes in "Pyrrhus and Cinéas." Beauvoir writes, "Man claims to transcend himself in God, but he never transcends himself except in the heart of immanence" ("Pyrrhus" 104). As we will see below, Beauvoir argues that it is not possible to be a for-itself-in-itself or God, but rather when the human being transcends she does so from her embodied being, thus bringing into focus the impossibility of being God. Sartre, on the other hand, believes that it is the nothingness of consciousness that allows for transcendence.

9 This puzzling term, "thises" ("les cecis"), is used by Sartre in Being and Nothingness to refer to the things or objects encountered by consciousness.

${ }^{10}$ For Sartre, it is consciousness that is nothingness. However, when he discusses the body and the present as the conditions of possibility of the nihilating activity of consciousness, he refers to them as being nothing in themselves. They are merely hinges - empty ones at that, but they are necessary for consciousness to do what it does.

${ }^{11}$ Sartre explains that the world and the body serve as a ground for consciousness. He says, "To be conscious is always to be conscious of the world, and the world and body are always present to my consciousness although in different ways" (Being and Nothingness 439-440).

${ }^{12}$ For more on Sartre's views on the body, see Katherine J. Morris, ed.

13 The discussion that follows in this section draws from the in-depth comparison between Beauvoir's and Sartre's views of embodiment and sexuality in Daigle, "Where Influence Fails".

14 In part IV, chapter 1, "Being and Doing: Freedom," Sartre explores the question of what happens when my body "resists" my consciousness. In the example of the hiker, he explains that free consciousness may circumvent the body's fatigue if it wills to do so. If it gives in to the fatigue, again it is freely that it does so. The hiker uses the body as a tool in the context of one's project and can freely decide to use it or not. The fatigue that is experienced is a factor in the body that does not transform the way consciousness exists, although technically, it should, if consciousness is embodied in the way Sartre has suggested. This is indicative of how Sartre departs from his own theoretical positions on embodiment. What this example shows, is that ultimately, for Sartre, consciousness can transcend its immanence, disregard it, and direct it at will.

${ }^{15}$ Sartre's approach to this is clearly machistic and stereotypical, as has been argued in Daigle, "Where Influence Fails." See also Margery L. Collins and Christine Pierce.

${ }^{16}$ Holes appear in the context of another famous example of the self-other relation: the peeping Tom. The peeping Tom is transformed from a subject who looks-at to a looked-at object when the gaze is turned on him. Looking through a keyhole, the peeping Tom seeks to find out what is happening in the room. He is transformed from an onlooker (subject) to a looked-at object when 
he hears a noise and thinks someone sees him looking through the keyhole. This interaction with a hole is equally defeating for the consciousness that becomes objectified in both cases.

${ }^{17}$ Arguing for a Sartrean ethics has been attempted, and sometimes with some success. However, when success is achieved, it seems that some bending is necessary. Thomas C. Anderson, for example, has used Beauvoir's Ethics of Ambiguity as if it was an instance of Sartrean ethics to explicate a Sartrean ethics. As we will make clear, however, Beauvoir's ethics is not Sartre'sand cannot be-since her views of intersubjective relations are so different from his. Bending Sartre's view is also bound to happen when one turns to Notebooks for an Ethics for help (wherein Sartre himself began to engage in some revisions of his views stemming from Being and Nothingness). In the Notebooks, he already begins to change some of his ontological/phenomenological views, especially when dealing with authenticity, arguably under the influence of Beauvoir (see Daigle, "The Ethics of Authenticity," where the ethics of authenticity is presented as the result of Beauvoir's influence on Sartre). For an interesting argument about the viability of Sartre's ethics using the notion of play, see Linda A. Bell.

${ }^{18}$ It has been suggested to us that the passage we quoted on sexual relations, which we take as paradigmatic of interpersonal relations, is permeated with a heterosexist gendered view. This is a point that we did not want to stress, but one that has been criticized by many feminist thinkers. Given that sexual relations are infected by gendered heterosexist biases, they could in fact be the most risky of relations, at least for women.

${ }^{19}$ Some argue that Beauvoir borrowed from Sartre, but many argue that it was his ideas that she pushed against, and by so doing formulated her own particular philosophy. Most notably, see Kate Fullbrook and Edward Fullbrook.

${ }^{20}$ In Beauvoir's earlier works, such as "Pyrrhus and Cinéas," she makes a distinction between transcendence as generosity and transcendence as project. However, in her later works we could further divide transcendence as generosity into devotion and ambiguity. Devotion is best described in "The Woman in Love" in The Second Sex. On the other hand, generosity as ambiguous being is described as a reciprocation between two. We find this reading in the "Conclusion" of The Second Sex. This distinction is not within the purview of this article.

${ }^{21}$ In the first case, the free action (generosity) is confused with passivity and meaninglessness, and not an affirmation of freedom. For example, caring for an other being can be regarded as particular to an individual's social, historical, and cultural becoming - an individual ought to care for her elderly parents because it is her daughterly duty. This call to duty entails that she is not caring for her parents out of her own volition. In this likely reading, care-giving is simply part of an individual's situation and not a freely chosen project in which the individual invests herself. In the second case, the free action is confused with egocentricism. Beauvoir uses the example of tipping someone when he acts in a generous fashion. She argues that the tip is an insult given that tipping denies the freedom of the generous man. Tipping assumes that the generous man is in fact merely self-interested. He is simply being helpful to be paid (extra). 
However, assuming this would be a mistake insofar as generosity would cease to be if it is merely self-interested ("Pyrrhus" 124).

22 There are two aspects of subjectivity in this early work. This apparent dualism between interiority and exteriority leads to a somewhat dualistic reading of subjectivity that is not fully reconciled until Beauvoir's later works. In this early text Beauvoir writes that the subject is both an interiority and an exteriority. This conceptual separation allows her to unpack the nuances that shape one's relations with others. For instance, Beauvoir argues, "as freedom, the other is radically separated from me, no connection can be created from me to this pure interiority upon which even God would have no hold" ("Pyrrhus" 126). Such a freedom (one which would even escape God) suggests that freedom is implicit in one's very being. This interiority is conceptualized as the very core of one's life (128). Furthermore, one's interiority is unaffected by one's being-in-the-world with others. It is this interiority that allows for radical freedom by presumably bracketing socio-cultural limitations on our desires, our preferences, or our rejections.

${ }^{23}$ In The Second Sex, Beauvoir's explicit call for transcendence as project covers over her implicit call for generosity.

24 In The Second Sex, Beauvoir undoubtedly displays a tension in her thinking between reciprocity and recognition. However, the bond can most certainly be understood as rooted in reciprocity. Therefore, she does not stray too far from her ethics of ambiguity, even in this seminal text. In the Introduction, she reminds us that our engagement with the Other is always a moral engagement. Beauvoir explains, "Every subject plays his part as such specifically through exploits or projects that serve as a mode of transcendence; he achieves liberty only through a continual reaching out toward other liberties" (xxxiv).

${ }^{25}$ Sartre would agree with Beauvoir with regards to our situation. However, his insistence on absolute freedom and on the conflictual nature of interpersonal relationships entails that one's freedom is not dependent on that of the Other. In fact, it can flourish on its own terms. In Beauvoir, such an individual flourishing of freedom is inconceivable. For more on Beauvoir's situated freedom and how it led Sartre eventually to revise his views, see Sonia Kruks.

${ }^{26}$ In The Second Sex, Beauvoir shows us that the situation of woman is manifest from a visible difference. In the heterosexual relation this difference or lack (the hole) appeals to the for-itself as an emptiness that desires to be filled. Man sacrifices his immanent being as body through penetration in order that the plenitude of being exists. The for-itself abdicates itself so as to maintain the totality of the In-itself. This is strangely reminiscent of Sartre's reading of the female sex as lack. See Sartre, Being and Nothingness 782.

27 Jacques Derrida explains that the only way generosity can function is if it is a gift given and forgotten by both parties, so as to negate the problem of owing or being owed. Yet generosity binds the individual to others in ways that are very real, and this element of forgetting makes this bond even more real. Although generosity asks to be forgotten, the act of giving ties the generous 
person to the benefactor in a relationship that is not easily undone. In this fashion, generosity may in fact nurture the status quo insofar as forgetting is an integral part of the domination of one group or one individual over another group or over another individual (Derrida 30).

${ }^{28}$ Beauvoir argues that the original type of being is not the desire to be, but rather it is the desire to disclose being. Disclosure is the seemingly paradoxical double moment of merging with the world (presencing the self) and uprooting oneself from the world (presencing the world) - a dwelling-with. Beauvoir explains, "By uprooting himself from the world, man makes himself present to the world and makes the world present to him. I should like to be the landscape which I am contemplating, I should like this sky, this quiet water to think themselves within me, that it might be I whom they express in flesh and bone, and I remain at a distance. But it is also by this distance that the sky and the water exist before me. My contemplation is an excruciation only because it is also a joy. I cannot appropriate the snowfield where I slide. It remains foreign, forbidden, but I take delight in this very effort toward an impossible possession. I experience it as a triumph, not as a defeat" ("Must We Burn Sade?" 12). This characteristic of consciousness, which Beauvoir terms a joy, presences the world, others, and objects so that consciousness may disclose by receding into the background. Self-consciousness can never completely take its leave because the individual, although a being-with also remains at a distance, and can never be one with the sky, the water, or the snowfield. Disclosure, for Beauvoir, is a positive movement. It is the fundamental type of being qua human being.

${ }^{29}$ For Sartre, there are three $e k$-stases of the for-itself: temporal (past, present, future), reflection, and being-for-others. In all cases, the for-itself is what it is not and is not what it is. In this fashion, the for-itself is a flight from oneself. These features of the for-itself can be found in The Second Sex; however, an exploration of Beauvoir's usage of Sartre's three ek-stases of the foritself would lead us too far afield.

${ }^{30}$ Marxist thinking, which is of great interest to Beauvoir and has influenced her thought, construes reproduction as non-creative and non-productive of surplus value. For the influence of Marx's thought on Beauvoir, see Eva Lundgren-Gothlin.

31 According to Sartre, being for-itself aims to be a being for-itself-in-itself. This is the unrealizable desire to be God. See Sartre, Being and Nothingness Part IV.

32 This sounds like the successful encounter between consciousnesses that is the aim of the intimate encounter for Sartre. See our first section, "Sartre on Transcendence." 


\section{Works Cited}

Anderson, Thomas C. The Foundation and Structure of Sartrean Ethics. Lawrence: Regents Press of Kansas, 1979.

-. Sartre's Two Ethics: From Authenticity to Integral Humanity. Chicago: Open Court, 1993.

de Beauvoir, Simone. The Ethics of Ambiguity. Trans. Bernard Frechtman. New York: Citadel Press, 1976.

—. "Must We Burn Sade?" The Marquis de Sade: An Essay by Simone de Beauvoir. Trans. Paul Dinnage. London: John Calder, 1962. 11-82.

—. "Pyrrhus and Cinéas." Simone de Beauvoir: Philosophical Writings. Ed. Margaret A. Simons, Marybeth Timmermann and Mary Beth Mader. Trans. Marybeth Timmermann. Urbana: University of Chicago Press, 2004. 77-150.

- The Second Sex. Trans. and Introduction H. M. Parshley. New York: Vintage Books, 1989.

Bell, Linda A. Sartre's Ethics of Authenticity. Tuscaloosa: University of Alabama Press, 1989.

Collins, Margery L. and Christine Pierce. "Holes and Slime: Sexism in Sartre's Psychoanalysis." Philosophical Forum (Boston) 5, (1973): 112-127.

Daigle, Christine. "The Ethics of Authenticity." Reading Sartre. Ed. J. Webber. London: Routledge, 2010. 1-14.

Daigle, Christine. "Where Influence Fails: Embodiment in Beauvoir and Sartre." Beauvoir and Sartre: The Riddle of Influence. Ed. C. Daigle and J. Golomb. Bloomington: Indiana University Press, 2009. 30-48.

De Coorebyter, Vincent. "Introduction." La Transcendance de l'Ego et autres textes phénoménologiques. By Jean-Paul Sartre. Paris: Vrin, 2003. 7-81.

Derrida, Jacques. Given Time: I. Counterfeit Money. Trans. Peggy Kamuf. Chicago: University of Chicago Press, 1992.

Diprose, Rosalyn. Corporeal Generosity: On Giving with Nietzsche, Merleau-Ponty, and Levinas. Albany: State University of New York Press, 2002.

Fullbrook, Kate and Fullbrook, Edward. Sex and Philosophy: Rethinking de Beauvoir and Sartre. London: Continuum, 2008. 
Kruks, Sonia. "Simone de Beauvoir: Teaching Sartre About Freedom." Sartre Alive. Ed. R. Aronson and A. van den Hoven. Detroit: Wayne State University Press, 1991. 285300 .

Lundgren-Gothlin, Eva. Sex and Existence: Simone de Beauvoir's The Second Sex. Trans. Linda Schenck. Hanover, NH: Wesleyan University Press, 1996.

Morris, Katherine J., ed. Sartre on the Body. Houndmills: Palgrave Macmillan, 2010.

Morris, Phyllis Sutton. "Sartre on the Transcendence of the Ego." Philosophy and Phenomenological Research 46 (1985): 179-198.

Priest, Stephen. The Subject in Question: Sartre's Critique of Husserl in The Transcendence of the Ego. New York: Routledge, 2000.

Sartre, Jean-Paul. Being and Nothingness. Trans. and Introduction Hazel Barnes. New York: Washington Square Press, 1984.

—. "Conscience de soi et connaissance de soi." Sartre: La Transcendance de l'Ego et autres textes phénoménologiques. Par Jean-Paul Sartre. Textes introduits et annotés par V. de Coorebyter. Paris: Vrin, 2003.

—. L'Être et le néant. Paris: Gallimard, 1943.

—. Notebooks for an Ethics. Trans. David Pellauer. Chicago: Chicago University Press, 1992.

-. The Transcendence of the Ego. An Existentialist Theory of Consciousness. Trans. Forrest Williams and Robert Kirkpatrick. New York: Noonday Press, 1957.

Veltman, Andrea. "The Concept of Transcendence in Beauvoir and Sartre." Beauvoir and Sartre: The Riddle of Influence. Ed. C. Daigle and J. Golomb. Bloomington: Indiana University Press, 2009. 222-240. 